\title{
Politically Connected Independent Directors and Effective Tax Rates in China
}

\author{
Hong Fan (corresponding author) \\ Department of Accounting, Saint Mary’s University \\ 923 Robie Street, Halifax, NS Canada \\ E-mail: Hong.fan@smu.ca \\ Liqiang Chen \\ Department of Finance, Information Systems and Management Science \\ Saint Mary's University \\ 923 Robie Street, Halifax, NS Canada \\ E-mail: Liqiang.chen@smu.ca
}

Received: March 2, 2017 Accepted: May 27, $2017 \quad$ Published: June 1, 2017

doi:10.5296/ajfa.v9i1.11129 URL: http://dx.doi.org/10.5296/ajfa.v9i1.11129

\begin{abstract}
This paper empirically investigates politically connected independent directors in Chinese public firms using 200 state-owned enterprises (SOEs) and 200 non-SOEs from 2002-2014. We find that, in general, firms with politically connected independent directors have higher effective tax rates than firms without such directors. We argue this is because that politically connected independent directors work for the interests of the government and restrict firms' tax planning activities. Additionally, the effect of politically connected directors on tax rates is weaker in SOEs than in non-SOEs, possibly because of the redundancy of the political ties that both independent directors and ownership bring in SOEs. Our study reveals the potential cost of political connections that prior studies have overlooked.
\end{abstract}

Keywords: tax planning, effective tax rates, Chinese SOE, independent directors, corporate governance 


\section{Introduction}

Studies have found political connections to be critical to a firm's success in a transitioning or emerging economy such as China's (Conyon, He, \& Zhou, 2015; Li \& Zhang, 2007; Li, Meng, \& Zhang, 2006). China's economy has become the second largest in the world, and analysts expect it to grow to become the largest very soon. However, China's economic system still needs many improvements such as enhancing investor protection, strengthening institutional support, increasing contract and property rights enforcement, and decreasing government interventions ( $\mathrm{Li}, \mathrm{Meng}$, Wang, \& Zhou, 2008). The literature documents that a firm's political connections could work as a substitute for formal institutions to overcome the voids in China's weak institutional environment and allow the firm to expand to more markets (Luo, 2003), access capital more easily(Wu, Wu, \& Liu, 2008), enjoy a lower cost of capital(Fan\& Hope, 2013), and enhance its monopoly status (Naughton, 2008). While the extant literature focuses on the political connections that CEOs (Wu et al., 2008)or firm ownership (Fan\& Hope, 2013)bring, scholars seldom study the political connections of the board - especially those of independent directors' political connections(Wang, 2015).

This study fills the gap in the literature by investigating the association between politically connected independent directors and the extent of tax aggressiveness in Chinese public firms. Tax aggressiveness is the downward manipulation of tax burden (Frank, Lynch, \& Rego, 2009). By definition, independent directors have no relation with the controlling party of their companies, and they are responsible for protecting shareholders-more importantly, minority shareholders-from expropriation by the management (Wang, 2015). However, in the Chinese context, the state tends to appoint politically connected independent directors to state-owned enterprises (SOEs) to influence their operations (Wang, 2015). Additionally, many non-SOEs welcome independent directors who have political connections with the government(i.e., politically connected independent directors), probably because of the firms' strong need for these connections. The strong need is induced by the benefits of political connections as discussed earlier.

In 2013, 44.9\% of independent directors in the firms listed on the Shanghai and Shenzhen stock exchanges had political backgrounds. ${ }^{1}$ On the one hand, shareholders may react positively to politically connected independent directors because their political connections could help their firms enjoy preferential treatment from the government, such as a lower borrowing rate from government controlled banks, which could improve firms' performance and value. On the other hand, shareholders may be concerned about whether these independent directors will expropriate them on behalf of the government. One common way of expropriation is to require firms be less aggressive in tax saving or even pay more taxes to the government, because a politically connected independent director is closely aligned with the government and may influence a firm's tax behaviors for the interest of the government. Therefore, a politically connected independent director may expropriate the shareholders' interests to some extent.

Prior studies show that the behaviors of SOEs and non-SOEs are different because of their

${ }^{1}$ http://fanfu.people.com.cn/n/2013/0909/c64371-22852586.html (in Chinese) 
ownership structures. For example, SOEs are generally less aggressive in earnings management than non-SOEs are (Wang \& Yung, 2011). The majority shareholder of a SOE is the state, which means that SOEs have inherent political connections, while non-SOEs strive to earn political connections via their top managers and/or board members. The state may appoint politically connected independent board members for SOEs, while non-SOEs may need to invite independent board members with political connections to join their boards. Because of these differences, politically connected independent board members may be more powerful in non-SOEs than SOEs. Furthermore, the government monitors the tax activities of SOEs by itself, so potential monitoring by independent directors might be redundant. However, in non-SOEs, politically connected board directors could be crucial to monitor tax activities for the government. In this paper, we also test whether the effect of politically connected independent directors on firms' tax aggressiveness is different for the two firm types.

By studying 400 public firms included in the Chinese Securities Index State-Owned Enterprises 200 (CSI SOE 200) and the Chinese Securities Index Privately-Owned Enterprises 200 (CSI POE 200) for the period 2002-2014, we find that cash effective tax rates (Cash ETRs) are positively associated with politically connected independent directors in Chinese firms. Further, the effect of politically connected independent directors is weaker for SOEs than for non-SOEs. Together, our results show that politically connected independent directors serve the interests of the state and closely monitor the tax activities of firms. As a result, firms with politically connected board directors pay more taxes than counterparts without politically connected independent directors. However, this does not necessarily mean that politically connected independent directors hurt the interests of shareholders even though they cause their firms to pay more taxes. Preventing firms from being tax aggressive could benefit shareholders in the long term. Studies have shown the tax aggressiveness may have negative impact on firm value, and the stock market reacts negatively to tax aggressive firms(Hanlon \& Slemrod, 2009).

Our study contributes both to the tax literature and the corporate governance literature. First, our study contributes to the understanding of the role of independent board directors in China, which is understudied in the literature (Wang, 2015). We find that firms with politically connected independent board director have higher Cash ETRs than other firms, suggesting that politically connected board directors represent the government and make firms comply with tax laws more strictly or even pay more taxes. Second, our finding contributes to the tax literature by identifying another way to prevent firms from being aggressive in tax planning. Finally, prior studies predict the differences in the behaviors between SOEs and non-SOEs due to their different ownership structures and major goals(Friedman, Johnson, \& Mitton, 2003; Johnson, La Porta, Lopez-de-Silanes, \& Shleifer, 2000; Liet al., 2008; Riyanto \& Toolsema, 2008). Our study supports this prediction by providing empirical evidence about the different impacts of politically connected board directors on firms' tax activities in SOEs and non-SOEs.

Our study has important practical implications as well. Although people commonly believe that obtaining a political connection is critical to a firm's success in China, they overlook the 
costs of that connection. Our study is one of the first to point out the potential cost of a political connection in China-more specifically, the additional taxes a firm with such a connection may pay to the government. China is opening to the world and has more investment opportunities for foreign investors; however, people's understanding of the Chinese business environment is still limited. Our study could interest companies that want to operate in China or collaborate with Chinese partners. Our findings reveal the necessary trade-off associated with politically connected board directors. Foreign firms in China should consider these costs and choose their optimal board structures.

The next section of this paper introduces regulations on independent board directors and related tax policies in China, reviews the literature, and proposes two hypotheses. The third section introduces the data and research design, followed by the empirical test results. The last section further discusses the results and concludes the paper.

\section{Literature Review and Hypotheses Development}

\subsection{Independent Board Directors and Political Connections in China}

The Shanghai and Shenzhen Stock Exchanges were established in 1990 and 1991, respectively. The first milestone for regulating independent board directors was the Guidance on the Establishment of an Independent Director System in Listed Companies (Guidance) that the China Securities Regulatory Commission issued in 2001. The Guidance required all public firms listed on the Shanghai or Shenzhen Stock Exchanges to include at least two independent directors on their boards of directors, and at least one of those independent board directors had to be in the accounting profession. Additionally, the independent directors had to make up a minimum of one-third of the total board members.

Although China's economy has developed significantly in the past 30 years, it is still less developed than those of Western countries. The gaps in the Chinese economic system include weak investor protection, weak institutional support, weak contract and property rights enforcement, and overreaching interventions by the government (Li et al., 2008). Studies prove that the political connections of firms effectively work as a substitute for formal institutions to overcome the gaps in China's weak institutional environment. For example, the political connection of a firm can help it expand to more markets (Luo, 2003), access capital more easily (Wu et al., 2008), enjoy a lower capital cost(Fan\& Hope, 2013), and enhance its monopoly status (Naughton, 2008).

Chinese firms strive to acquire political connections because of the enormous benefits they provide. SOEs have inherent political connections because their controlling shareholder is the government. The government tends to appoint politically connected independent board directors to sit on boards to direct SOEs to operate in its best interests. Non-SOEs could gain political connections via their CEO and/or managers' political ties and invite politically connected independent board directors to sit on their boards. In $2013,44.9 \%$ of the independent board directors in firms listed on the Shanghai and Shenzhen Stock Exchanges had political connections.

The literature usually refers to two types of political connections: past working experience in 
the government or military, and membership in two key institutions of the central government - the National People's Congress (NPC) and the Chinese People's Political Consultative Conference (CPPCC) (Conyon at al., 2015; Li et al., 2008). Both the NPC and CPPCC operate at central and local levels. The NPC is a legislative authority in the government, and NPC members have the right to vote on laws and official appointments, whereas the CPPCC is a consultative organization that provides suggestions and comments to the government (Guo, 2001).

By 2013, independent board directors who were retired government officials were receiving considerable attention from the media because the public questioned their legitimacy. ${ }^{2}$ Investors were concerned that officials might bestow unearned benefits on firms before retiring from the government to secure positions as independent directors because the salary for an independent director is significant. The public was also concerned about whether retired officials might provide special treatment to these firms such as leaked confidential information.

To regulate independent directors further, the Organization Department of the Communist Party of China (ODCPS) issued the Opinions on Further Regulating the Issue of Part-time (Post-Service) Work of Party and Government Leading Officers in Enterprises in October 2013, which requires government officials to justify positions they served with enterprises within three years of retirement. After three years, firms that hire former government officials need to report their hiring to the relevant government entity. Additionally, no former officials can work for any firm without government approval. After the ODCPS issued this regulation, most retired officials resigned from their positions as independent directors. In our study, we did not include the past working experience in the definition of political connection and focused on the other type of political connection: NPC membership and/or CPPCC membership. We define "politically connected independent directors" as ones who are or were NPC or CPPCC members.

\subsection{Chinese Income Tax Policy}

China began transitioning from a planned economy to a market economy in the late 1970s. In 1994, it enforced the Corporate Income Tax Code to regulate tax policies. At the time, China had just opened its door the outside of the world, and it was striving to attract foreign investors to raise funds and learn about management practices, advanced technology, and so on. Therefore, the Chinese government offered different income tax rates to domestic and foreign firms. Before 2008, domestic companies in China faced a tax rate of 33\%, while foreign firms faced rates as low as $15 \%$ - not to mention additional preferential tax treatments they received. The different tax rates competitively disadvantaged domestic Chinese firms. In 2008, the Chinese government enacted the uniform version of the Corporate Income Tax Law to make the tax rates the same for both domestic and foreign firms. ${ }^{3}$

China classifies taxes as central and local which the central and local governments collect,

\footnotetext{
2 http://www.qikan.com/article/74A54C7A-3072-404D-A6F6-A6B95997C0F4 (in Chinese)

${ }^{3}$ http://finance.sina.com.cn/g/20070227/00493357397.shtml (in Chinese)
} 
respectively( $\mathrm{Wu}, \mathrm{Wu}, \mathrm{Zhou}, \& \mathrm{Wu}, 2012)$. For example, duties are central taxes while personal income taxes are local taxes. The central government collects income taxes of SOEs it controls. The central and local governments share income taxes from non-SOEs and SOEs that the local government controls. Income taxes from enterprises are an important source of revenue for the central government and are the main sources of revenue for the local government. Therefore, the government enforce tax practices in several ways, including annual tax auditing by the National Taxation Bureau and provincial bureaus.

\subsection{Tax Aggressiveness and Politically Connected Board Directors}

The literature commonly defines "tax aggressiveness" as the downward manipulation of tax burdens of firms (Frank et al., 2009). Many researchers have found that corporate government mechanisms are significantly associated with tax aggressiveness(Desai \& Dharmapala, 2008; Shleifer \& Vishny, 1997). Good corporate governance such as the presence of independent directors is one mechanism that may mitigate tax aggressiveness.

However, Chinese independent directors with political connections may act differently than their counterparts without political connections. Politically connected independent board directors who have relationships with the government may act in the best interests of the government instead of shareholders. Independent directors may prioritize government interests because their political connections are their capital assets rather than firm assets. These capital assets move with directors. At the same time, if directors act against the interests of the government, they may lose their political connections. We argue that independent directors will not risk their political ties with the government. If there is any conflict of interest between shareholders and the government, they will choose to protect government interests rather than shareholder interests, unlike independent directors in Western countries.

As discussed above, income taxes from enterprises are important sources of funds for both central and local governments. The governments expect firms to be less aggressive in tax planning so they can collect more tax. Therefore, we predict that politically connected independent board directors can restrict the tax planning activities of their firms, resulting in lower tax aggressiveness (i.e., higher effective tax rate). Our first hypothesis is:

Hypothesis 1: A firm's effective tax rate is positively associated with the presence of politically connected independent directors on its board.

\subsection{SOEs vs. non-SOES}

In 1978, China opened its market to the world and started transitioning from a planned economy to a market economy. To modernize SOEs and increase their profitability, the Chinese government decided to separate the ownership of these organizations from their management. In fact, the term "state-owned enterprises" was first introduced during this period of transition(Fan \& Hope, 2013). The state still owned and controlled most firms, but this separation gave SOEs more autonomy in running their businesses while also providing them with incentives to improve their performance. The government has controlled SOEs via the State-Owned Assets Supervision and Administration Commission (SASAC) since it created the SASAC in 2003. On behalf of the central government, the national SASAC 
supervises the 112 central SOEs, but it is not involved in any of their daily operations. ${ }^{4}$ Subnational SASACs at the provincial, municipal, and county levels supervise the non-central SOEs, and the role of these subnational SASACs is similar to that of the national SASAC. The SASAC controls the performance of SOEs by appointing managers, evaluating enterprise performance, and so on.

SOEs and non-SOEs behave differently; for example, SOEs are found to be less aggressive in boosting their income. $\mathrm{Li}$ et al. (2008) speculate that the main goals of these two types firms are different. While non-SOEs aim to maximize their profit, SOEs need to fulfill their social and political responsibilities. This explains the findings in the literature regarding their different behaviors. Wu et al. (2012) provide empirical evidence to support Li et al.'s conjecture. They find that the effects of political connections on firms are different for SOEs and non-SOEs. Private firms with politically connected CEOs outperform their counterparts without politically connected CEOs, whereas local SOEs with politically connected CEOs underperform compared to their counterparts that lack politically connected CEOs. Local SOEs may prioritize their social and political needs (e.g., lower unemployment rates) and sacrifice some business profits. Wang (2015) provides further evidence of $\mathrm{Li}$ et al.'s speculation by finding that non-SOEs with politically connected board directors can access external debt more easily than their non-connected counterparts can, while politically connected board directors in SOEs do not have a significant impact on their firms. Wang argues that this is because SOEs care less about profits than non-SOEs do, so they do not try as hard to access external debt as non-SOEs. Thus, independent directors in SOEs do not use their political connections to help them access debt.

An alternative explanation of the findings of Wang (2015) might be that SOEs have political connections from their state ownership, so the political connections associated with CEOs and/or independent directors are redundant. SOEs may have easier access to external debt due to the political connections brought by the government ownership, and the political connections associated with managers or board members do not have significant incremental impact on obtaining external debt.

We predict that the effects of the political connections of board directorsare weaker in SOEs than in non-SOEs, in line with the prior literature. In non-SOEs, politically connected board directors would work in the interest of the government and closely monitor the firms' tax activities as argued in hypothesis 1 . However, in SOEs, the government influences SOEs' tax activities via their controlling of the firm, its influence on the CEOs, and policies, making the monitoring of the politically connected board directors redundant. We predict the tax monitoring effect of the politically connected board director is weaker in SOEs than in non-SOEs. Our second hypothesis is:

Hypothesis 2: The association between effective tax rate and the presence of politically connected independent board directors is weaker in SOEs than in non-SOEs.

${ }^{4}$ http://www.sasac.gov.cn/n1180/n1226/n2425/index.html 


\section{Data and Research Design}

\subsection{Data}

Our sample consists of 400 firms included in both the CSI SOE 200and CSI POE 200 for 13 years from 2002 to 2014 based on the index components of 2014. The 200 firms in CSI SOE (POE) 200 are the state-owned (privately-owned) firms with the largest market capitalization and liquidity of all the public A-share companies listed on the Shanghai or Shenzhen Stock Exchanges.

Our data collection began with gathering director names and types (independent or not) from audited annual financial statements. Once we obtained the names of independent directors, we followed prior research (Peng, Sun, \& Markóczy, 2015) and collected independent directors' background information and NPC/CPPCC membership from the Profile of Directors and Senior Managers sections in the annual reports. Because disclosing NPC/CPPCC membership is voluntary, we retrieved the full list of members of the national NPC and CPPCC from their official websites and searched the names of each independent director in the last 20 years. If we found a relevant name on this list, we then further checked whether the member was the same individual as the director in our sample by searching for additional information about him or her such as news and pictures. We defined a politically connected independent director (PBoard) as a dummy variable equal to 1 if at least one independent director on the board is or was a member of the NPC or CPPCC and equal to 0 otherwise.

To control for CEOs' political connections, we performed the same procedure for independent directors' political connections to collect information about CEO's political connections. We defined politically connected CEOs (PCEO) as a dummy variable equal to 1 if the CEO is or was a member of the NPC or CPPCC and equal to 0 otherwise. We also obtained CEO tenure data from the Profile of Directors and Senior Managers sections of annual reports. We retrieved financial- and market-related data from Capital IQ.

Table 1 describes our data selection procedure. Of the 5,200 (400 firms x 13 years) firm-year observations, 594went public after the initial sample year of 2002, thus reducing our sample size. Among the remaining observations, 872 were missing political connection information on CEOs and/or board members from their annual reports. We then merged the data with finance- and market-related data from Capital IQ. After we deleted cases with missing data, the final sample size had 3,147 firm-year observations.

A preliminary analysis of the data indicated certain extreme values. To reduce the effect of these outliers on the results, we winsorized all the continuous variables by $1 \%$ at the top and 99\% at the bottom, including cash effective tax rate (ETR), firm size, tenure, return on assets (ROA), market-to-book ratio, leverage, capital intensity, and inventory intensity.

\subsection{Research Design}

There are many ways to measure the aggressiveness of tax planning such as Generally Accepted Accounting Principles effective tax rate (GAAP ETR), Cash ETR, book-tax 
difference (BTD), and discretionary book-tax difference (DBTD)(Lennox, Lisowsky, \& Pittman, 2013). We believe that Cash ETR should be the best measure for our study. We argue that politically connected board members might require their firms to be less aggressive in tax savings or even pay more taxes because they act in the best interests of the government. The government cares more about the amount of cash tax collected than it cares about other measures of tax aggressiveness, because it collects cash to run its daily operations. Therefore, we used Cash ETR as our dependent variable.

Our sample consists of panel data. We first performed Hausman tests to compare a fixed effect model with random effect model and ordinary least squares model. The fixed effect model was preferred over the other two models.

To test Hypothesis 1, we used Cash ETRs as our dependent variable and controlled for the basic determinants of Cash ETRs, including return on assets (ROA), market-to-book ratio (MTB), leverage (LEV), CEO Tenure (Tenure), capital intensity (FIX), inventory intensity (INV), net loss carry forward (LOSS), and size (SIZE)(Rego\& Wilson, 2012; Zeng, 2010). We also included the dummy variable of PCEO to measure the political connection of $\mathrm{CEO}(\mathrm{Wu}$ et al., 2012). We used the industry fixed effect model to control for any other industry-level characteristics. Next, we incorporated our test variable PBoard in the model. Our model is:

$$
\begin{gathered}
\text { Cash ETR }_{i t}=\beta_{0}+\beta_{1} \text { PBoard }_{i t}+\beta_{2} \text { PCEO }_{i t}+\beta_{3} \text { SIZE }_{i t}+\beta_{4} M T B_{i t}+\beta_{5} L E V_{i t}+\beta_{6} I N V_{i t}+\beta_{7} F I X_{i t} \\
+\beta_{8} \text { Tenure }_{i t}+\beta_{9} \text { ROA }_{i t}+\beta_{10} \text { LOSS }_{i t}+\beta \text { Years } \\
\varepsilon_{i t}
\end{gathered}
$$

where

Cash $E T R_{i t}=$ Cash ETR is income taxes paid divided by pre-tax income for year $\mathrm{t}$;

PBoard $_{i t}=$ The politically connected independent director is a dummy variable that equals 1 if at least one independent director on board is or was a member of NPC or CPPCC and equals 0 otherwise;

$P C E O_{i t}=$ The politically connected $\mathrm{CEO}$ is a dummy variable that equals 1 if the CEO is or was a member of NPC or CPPCC and equals 0 otherwise;

$S I Z E_{i t}=$ Size is the natural log of the market value;

$M T B_{i t}=$ Market-to-book ratio is the market value of common equity divided by the book value of common equity at the end of the current year;

$L E V_{i t}=$ Leverage is the long-term debt of the current year-end divided by the book value of equity at current year-end;

$I N V_{i t}=$ Inventory intensity is the total inventory of current year-end divided by the total assets of the firm at current year-end;

$F I X_{i t}=$ Capital Intensity is the total fixed assets for the current year-end divided by the total assets of the firm at current year-end;

Tenure $_{i t}=$ Tenure is the number of years the CEO serves in this position; 
$R O A_{i t}=\mathrm{ROA}$ is the net income for firm $i$ in year $t$ divided by total assets for firm $i$ in year $t-1$

$\operatorname{LOSS}_{i t}=$ Loss is a dummy variable that assumes the value of 1 if there is a net loss carry forward and 0 otherwise.

The data would support Hypothesis 1 if $\beta_{1}$ is positive and significant, suggesting that firms with politically connected board directors pay higher taxes for each dollar income than firms without politically connected board directors do, probably because of the strong tax monitoring of these politically connected board directors on behalf of the government.

To test Hypothesis 2, we used a similar model as previously described, and we introduced the interaction of PBoard and the dummy variable of SOE to the model. If the interaction of PBoard and SOE was negative and significant, the data would support Hypothesis 2, indicating that the tax monitoring effect of politically connected independent board directors is weaker in SOEs. The model is:

Cash ETR $_{i t}=\beta_{0}+\beta_{1}$ PBoard $_{i t}+\beta_{2}$ SOE $_{i} *$ PBoard $_{i t}+\beta_{3}$ SOE $_{i}+\beta_{4}$ PCEO $_{i t}+\beta_{5}$ SIZE $_{i t}+\beta_{6}$ $M T B_{i t}+\beta_{7} L E V_{i t}+\beta_{8} I N V_{i t}+\beta_{9}$ FIX $_{i t}+\beta_{10}$ Tenure $_{i t}+\beta_{11}$ ROA $A_{i t}+\beta_{12}$ LOSS $_{i t}+\beta$ Years $+\varepsilon_{i t}$

where

$S O E_{i}=\mathrm{SEO}$ is a dummy variable that takes the value of 1 if the firm is included in the CSI SOE 200 index and takes the value of 0 if the firm is included in the CSI POE 200 index.

\section{Empirical Results}

\subsection{Descriptive Statistics}

Table 2 reports the summary statistics for the variables. Panel A reports the descriptive statistics for the dependent variable (Cash ETR), and Panel B reports the descriptive statistics for the continuous variables (ROA, MTB, LEV, Tenure, FIX, INV, and SIZE). Panel C presents the descriptive statistics for the discrete variables (PBoard, PCEO, SOE, and LOSS).

Panel A indicates that the mean level of Cash ETR is $43.3 \%$, which is higher than other studies(e.g., Wu et al., 2012). We speculated this is because we include only large size firms (i.e., largest 200 SOEs and largest 200 POEs) in our study. Larger firms are less aggressive in tax saving for several reasons, such as more analysts following larger firms, the higher reputation costs for larger firms. In addition, we cover more current sample years. We tested the tax behavior of Chinese public firms with a sample extending to 2014, while other studies focused on the period prior to 2008(Wu et al., 2012; Zeng, 2010).

Panel C presents the descriptive statistics for PBoard, PCEO, SOE, and LOSS. Our data show that about $20 \%$ of firm-year observations have the independent board directors with political connections via NPC or CPPCC membership and that about $18 \%$ of the CEOs were NPC or CPPCC members, consistent with prior studies (Wu et al., 2012). The SOEs and non-SOEs were almost equally distributed in our sample. The other control variable statistics presented in Panel B were generally consistent with Zeng (2010). 
Table 3 presents the Pearson correlation matrix for independent variables. No correlations are higher than $50 \%$, suggesting that multicollinearity is not a significant concern in this study.

\subsection{Regression Results for Hypotheses 1 and 2 (Table 4)}

Table 4 shows the results of hypotheses tests using multivariable regression. Model 1 presents the regression results of equation 1 and tests Hypothesis 1. Model 2 presents the regression results of equations 1 and 2 and tests Hypotheses 1 and 2 simultaneously.

In Model 1, PBoard is positively and significantly associated with the dependent variable Cash ETR, thus supporting Hypothesis 1. This result supports our argument that independent board directors work as brakes for firms' tax aggressive behaviors and require their firms to pay relatively more taxes than other firms do.

In Model 2, the interaction of PBoard and SOE was negative and significant, supporting Hypothesis 2 that the effect of politically connected independent board directors on tax is weaker in SOEs than in non-SOEs, probably because the government - as the majority shareholder - can monitor the behaviors of the SOEs by itself, rendering the monitoring function of politically connected board director redundant to some extent. Further, the coefficient of PBoard is positive and significant, while the sum of the coefficients of the PBoard and the interaction of PBoard and the SOE is not significantly different from 0 (untabulated), suggesting that non-SEOs mainly drive the positive relationship between PBoard and Cash ETR. This indicates that non-SEOs still support Hypothesis 1 and further supports Hypothesis 2. We also find that the average Cash ETR is higher for SOEs than it is for non-SOEs, consistent with prior studies.

Similar to Zeng (2010), we find ROA to be negatively associated with Cash ETR in our study. LOSS is also negatively associated with the Cash ETR. Firms with loss carry forward pay less tax. Both INV and FIX proxy the opportunities for firms to manipulate their taxes, and we find these two variables are positive and significant in Model 2. Further, PCEO is positively and significantly associated with Cash ETR, suggesting that CEOs with political connections are willing to pay relatively more taxes than CEOs without political connections are. Like politically connected independent board directors, politically connected CEOs are aligned with the government and may be more conservative in tax planning. Additionally, political connections are the assets of CEOs instead of firms. CEOs may not want to risk their political assets to benefit shareholders' interests, and they especially may not want to be aggressive in tax planning to please shareholders at the risk of upsetting the government.

\subsection{Robustness Tests (Tables 5)}

We conducted robustness tests to check whether our results were sensitive to the model we used and the measures of tax aggressiveness we adopted. We retested our two hypotheses by using Tobit model. Then we used GAAP ETR to retest the two hypotheses using both Fixed and Tobit models.

First, we reexamined the two hypotheses by using the Tobit model and reported on the results in the first column of Table 5. We expected Cash ETR to be within the range of 0 to 1, and we 
set the upper level to 1 and the lower level to 0 in the Tobit analysis. We found that the coefficient of PBoardwas positive and significant, and the coefficient of the interaction between PBoard and SOE was negative and significant, which is consistent with the findings in Table 4. Further, the data supports our two hypotheses.

Second, we changed the measure of tax aggressiveness and substituted GAAP ETR for Cash ETR. GAAP ETR is the income tax expense divided by the pretax income. GAAP ETR is an alternative way to measure tax aggressiveness and the literature widely uses it(Lennox et al., 2013). We reported regression results based on the fixed effect model in the second column of Table 5 and the results based on the Tobit model in the third column. GAAP ETR was positively and significantly associated with PBoard and was also negatively and significantly associated with the interaction of PBoard and SOE. The results suggest that firms with a politically connected independent board director have higher effective tax rates than firms without such directors do, but this effect is less strong in SOEs than in non-SOEs.

Taken together, the findings for the two hypotheses are robust to different models and to the different measures of tax effective rates.

\section{Discussion and Conclusion}

Our study investigates the association between Cash ETRs and politically connected board directors. We find that firms with at least one politically connected board director had higher Cash ETRs than firms without politically connected board directors did. Additional analyses showed that this association was stronger in non-SOEs than in SOEs. This result is robust to different models and different measures of tax aggressiveness.

Our findings highlight the potential costs (i.e., higher taxes) of independent board directors' political connections. However, a relatively higher Cash ETR is not necessarily bad for shareholders. The chance of a tax authority auditing a firm is significantly higher when its book-tax difference is larger (Mills, 1998), and the book-tax difference is the gap between financial income and taxable income. When firms are more aggressive in tax savings, the book-tax difference becomes larger and may attract more attention from the tax authority. If the tax authority discovers firms' tax aggressiveness, the stock market will react negatively to this news (Hanlon \& Slemrod, 2009). In the long run, being too aggressive in tax saving might hurt the interests of shareholders.

Our findings provide the boards of firms in China with a new angle to evaluate politically connected board directors. We recommend including at least one politically connected board director in non-SOE boards to gain political connections and act as a brake for tax aggressive activities. However, the value of such directors is not significant in SOEs. Our paper studied Chinese firms, so the results may not be generalizable to other countries due to its unique institutional context. We acknowledge this as a limitation of our paper.

\section{References}

Conyon, M. J., He, L., \& Zhou, X. (2015). Star CEOs or political connections? evidence from china's publicly traded firms. Journal of Business Finance \& Accounting, 42(3-4), 412-443. https://doi.org/10.1111/jbfa.12110 
Desai, M. A., \& Dharmapala, D. (2008). Tax and corporate governance: An economic approach. Tax and corporate governance (pp. 13-30) Springer. https://doi.org/10.1007/978-3-540-77276-7_3

Fan, G. \& Hope, N. (2013). The role of state-owned enterprises in the chinese economy. China US Focus.

Frank, M. M., Lynch, L. J., \&Rego, S. O. (2009). Tax reporting aggressiveness and its relation to aggressive financial reporting. The Accounting Review, 84(2), 467-496. https://doi.org/10.2308/accr.2009.84.2.467

Friedman, E., Johnson, S., \& Mitton, T. (2003). Propping and tunneling. Journal of Comparative Economics, 31(4), 732-750. https://doi.org/10.1016/j.jce.2003.08.004

Guo, S. (2001). The party-state relationship in post-mao china. China Report, 37(3), 301-315. https://doi.org/10.1177/000944550103700301

Hanlon, M., \&Slemrod, J. (2009). What does tax aggressiveness signal? evidence from stock price reactions to news about tax shelter involvement. Journal of Public Economics, 93(1), 126-141. https://doi.org/10.1016/j.jpubeco.2008.09.004

Johnson, S., La Porta, R., Lopez-de-Silanes, F., \& Shleifer, A. (2000). Tunneling. American Economic Review, 90(2), 22-27. https://doi.org/10.1257/aer.90.2.22

Lennox, C., Lisowsky, P., \& Pittman, J. (2013). Tax aggressiveness and accounting fraud. Journal of Accounting Research, 51(4), 739-778. https://doi.org/10.1111/joar.12002

Li, H., \& Zhang, Y. (2007). The role of managers' political networking and functional experience in new venture performance: Evidence from china's transition economy. Strategic Management Journal, 28(8), 791-804. https://doi.org/10.1002/smj.605

Li, H., Meng, L., Wang, Q., \& Zhou, L. (2008). Political connections, financing and firm performance: Evidence from chinese private firms. Journal of Development Economics, 87(2), 283-299. https://doi.org/10.1016/j.jdeveco.2007.03.001

Li, H., Meng, L., \& Zhang, J. (2006). Why do entrepreneurs enter politics? evidence from china. Economic Inquiry, 44(3), 559-578. https://doi.org/10.1093/ei/cbj031

Luo, Y. (2003). Industrial dynamics and managerial networking in an emerging market: The case of china. Strategic Management Journal, 24(13), 1315-1327. https://doi.org/10.1002/smj.363

Mills, L. F. (1998). Book-tax differences and internal revenue service adjustments.Journal of Accounting Research, 343-356. https://doi.org/10.2307/2491481

Naughton, B. (2008). SASAC and rising corporate power in china. China Leadership Monitor, 24(2), 1-9. 
Peng, M. W., Sun, S. L., \&Markóczy, L. (2015). Human capital and CEO compensation during institutional transitions. Journal of Management Studies, 52(1), 117-147. https://doi.org/10.1111/joms.12106

Rego, S. O., \& Wilson, R. (2012). Equity risk incentives and corporate tax aggressiveness. Journal of Accounting Research, 50(3), 775-810. https://doi.org/10.1111/j.1475-679X.2012.00438.x

Riyanto, Y. E., \&Toolsema, L. A. (2008). Tunneling and propping: A justification for pyramidal ownership. Journal of Banking \& Finance, 32(10), 2178-2187. https://doi.org/10.1016/j.jbankfin.2007.12.044

Shleifer, A., \&Vishny, R. W. (1997). A survey of corporate governance. The Journal of Finance, 52(2), 737-783. https://doi.org/10.1111/j.1540-6261.1997.tb04820.x

Wang, L. (2015). Protection or expropriation: Politically connected independent directors in china. Journal of Banking \& Finance, 55, 92-106. https://doi.org/10.1016/j.jbankfin.2015.02.015

Wang, L., \& Yung, K. (2011). Do state enterprises manage earnings more than privately owned firms? the case of china. Journal of Business Finance \& Accounting, $38(7-8)$, 794-812. https://doi.org/10.1111/j.1468-5957.2011.02254.x

Wu, W., Wu, C., \& Liu, X. (2008). Political connection and market valuation: Evidence from china individual-controlled listed firms [J]. Economic Research Journal, 7, 130-141.

Wu, W., Wu, C., Zhou, C., \& Wu, J. (2012). Political connections, tax benefits and firm performance: Evidence from china. Journal of Accounting and Public Policy, 31(3), 277-300. https://doi.org/10.1016/j.jaccpubpol.2011.10.005

Zeng, T. (2010). Ownership concentration, state ownership, and effective tax rates: Evidence from China's listed firms. Accounting Perspectives, 9(4), 271-289. https://doi.org/10.1111/j.1911-3838.2010.00014.x

Table 1. Sample Selection

\begin{tabular}{|l|c|}
\hline Initial Sample (firm-year observations) & 5,200 (a) \\
\hline Deletions due to missing data for & \\
Prior IPO & -594 \\
CEO's political connection & -811 \\
Board's political connection & -61 \\
Cash ETR in Capital IQ & -21 \\
Control variables & -566 \\
\hline Sample size & 3,147 \\
\hline
\end{tabular}

(a) CSI SOE 200 firms and CSI POE 200 firms 13 years (2002-2014) 
Table 2. Summary Statistics for Dependent and Independent Variables

\begin{tabular}{|c|c|c|c|c|c|}
\hline \multicolumn{6}{|c|}{ Panel A: Dependent Variables } \\
\hline Variables & Mean & Std Dev & 25th & 50th & 75th \\
\hline Cash ETR & 0.433 & 0.836 & 0.208 & 0.433 & 0.797 \\
\hline \multicolumn{6}{|c|}{ Panel B: Continuous Variables } \\
\hline Variable & Mean & Std Dev & 25th & 50th & 75th \\
\hline Tenure & 4.4903 & 3.3514 & 2 & 3 & 6 \\
\hline $\mathrm{ROA}$ & 5.0155 & 5.0921 & 1.780 & 3.880 & 7.150 \\
\hline $\mathrm{LEV}$ & 0.2221 & 0.1652 & 0.078 & 0.212 & 0.337 \\
\hline MTB & 3.6569 & 2.8570 & 1.756 & 2.745 & 4.603 \\
\hline FIX & 0.2712 & 0.1983 & 0.115 & 0.237 & 0.394 \\
\hline INV & 0.1670 & 0.1582 & 0.056 & 0.130 & 0.218 \\
\hline SIZE & 9.1942 & 1.8707 & 7.923 & 8.914 & 10.169 \\
\hline \multicolumn{6}{|c|}{ Panel C: Discrete variables } \\
\hline Variable & Value & & & Value & Percent \\
\hline PBoard & 1 & & & 0 & $80.33 \%$ \\
\hline PCEO & 1 & & & 0 & $82.43 \%$ \\
\hline SOE & 1 & & & 0 & $47.41 \%$ \\
\hline LOSS & 1 & & & 0 & $96.16 \%$ \\
\hline \multicolumn{6}{|c|}{ Variable definitions } \\
\hline \multicolumn{6}{|c|}{$\overline{\text { Dependent variable: }}$} \\
\hline \multicolumn{6}{|c|}{$\begin{array}{l}\text { Cash } \mathrm{ETR}_{\mathrm{it}}=\text { Cash ETR calculated as income taxes paid divided by the pre-tax income in year } \mathrm{t} \text {; } \\
\text { Independent variables: }\end{array}$} \\
\hline \multicolumn{6}{|c|}{ Tenure $=$ Number of years the CEO serves in this position; } \\
\hline \multicolumn{6}{|c|}{ 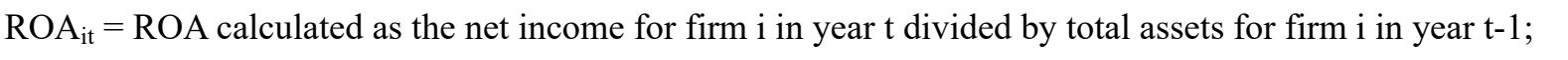 } \\
\hline \multicolumn{6}{|c|}{$\begin{array}{l}\mathrm{MTB}_{\mathrm{it}}=\text { Market-to-book ratio calculated as the market value of common equity divided by book value of } \\
\text { common equity at end of current year; }\end{array}$} \\
\hline \multicolumn{6}{|c|}{$\begin{array}{l}\mathrm{LEV}_{\mathrm{it}}=\text { Leverage calculated as long-term debt at current year-end divided by book value of equity at current } \\
\text { year-end; }\end{array}$} \\
\hline \multicolumn{6}{|c|}{$\begin{array}{l}\text { FIX } \\
\text { it }=\text { Capital Intensity calculated as total fixed assets at current year-end divided by total assets of the firm } \\
\text { at current year-end; }\end{array}$} \\
\hline \multicolumn{6}{|c|}{$\begin{array}{l}\mathrm{INV}_{\text {it }}=\text { Inventory Intensity calculated as total inventory at current year-end divided by total assets of the } \\
\text { firm at current year-end; }\end{array}$} \\
\hline \multicolumn{6}{|c|}{$\mathrm{SIZE}_{\mathrm{it}}=$ natural log of market value; } \\
\hline \multicolumn{6}{|c|}{ Discrete variables: } \\
\hline \multirow{2}{*}{\multicolumn{6}{|c|}{$\begin{array}{l}\text { PBoard }_{i t}=\text { The politically connected independent director is a dummy variable that equals to } 1 \text { if at least one } \\
\text { independent director on board is or was a member of NPC or CPPCC, and equals to } 0 \text { otherwise; } \\
\text { PCEO }_{\text {it }}=\text { The politically connected CEO is a dummy variable that equals to } 1 \text { if the CEO is or was a member } \\
\text { of NPC or CPPCC, and equals to } 0 \text { otherwise; }\end{array}$}} \\
\hline & & & & & \\
\hline \multicolumn{6}{|c|}{$\begin{array}{l}\mathrm{SOE}_{\mathrm{i}}=\mathrm{SEO} \text { is a dummy variable that takes the value of } 1 \text { if the firm is included in the CSI SOE } 200 \text { index, } \\
\text { and take the value of } 0 \text { if the firm is included in the CSI POE } 200 \text { index; }\end{array}$} \\
\hline \multicolumn{6}{|c|}{$\mathrm{LOSS}_{\text {it }}=$ Loss is a dummy variable that takes value of 1 if there is a net loss carry forward and 0 otherwise. } \\
\hline
\end{tabular}


Table 3. Correlations

\begin{tabular}{|c|c|c|c|c|c|c|c|c|c|c|c|}
\hline & \multirow{2}{*}{$\begin{array}{l}\text { Cash } \\
\text { ETR }\end{array}$} & \multirow{2}{*}{$\begin{array}{c}\text { PBoar } \\
\text { d }\end{array}$} & \multicolumn{3}{|c|}{ PCE } & \multirow[b]{2}{*}{ MTB } & \multirow[b]{2}{*}{ LEV } & \multirow[b]{2}{*}{ INV } & \multicolumn{3}{|c|}{ Tenur } \\
\hline & & & SOE & $\mathrm{O}$ & SIZE & & & & FIX & $\mathrm{e}$ & ROA \\
\hline \multicolumn{12}{|l|}{ PBoar } \\
\hline d & 0.010 & 1.000 & & & & & & & & & \\
\hline \multirow[t]{2}{*}{ SOE } & 0.091 & 0.199 & 1.000 & & & & & & & & \\
\hline & & & -0.02 & & & & & & & & \\
\hline PCEO & 0.065 & 0.064 & 5 & 1.000 & & & & & & & \\
\hline \multirow[t]{2}{*}{ SIZE } & 0.070 & 0.320 & 0.469 & 0.153 & 1.000 & & & & & & \\
\hline & & & -0.16 & -0.08 & -0.34 & & & & & & \\
\hline \multirow[t]{2}{*}{ MTB } & -0.093 & -0.127 & 4 & 8 & 6 & 1.000 & & & & & \\
\hline & & & -0.05 & & & -0.16 & & & & & \\
\hline \multirow[t]{2}{*}{ LEV } & 0.070 & -0.017 & 8 & 0.013 & 0.046 & 7 & 1.000 & & & & \\
\hline & & & -0.09 & & -0.05 & -0.00 & & & & & \\
\hline \multirow[t]{2}{*}{ INV } & 0.097 & -0.097 & 0 & 0.039 & 4 & 2 & 0.188 & 1.000 & & & \\
\hline & & & & -0.00 & -0.08 & -0.10 & & -0.33 & & & \\
\hline \multirow[t]{2}{*}{ FIX } & 0.089 & -0.020 & 0.124 & 5 & 2 & 7 & 0.313 & 8 & 1.000 & & \\
\hline & & & -0.07 & & & -0.02 & -0.04 & & -0.08 & & \\
\hline \multirow[t]{2}{*}{ Tenure } & 0.043 & 0.019 & 6 & 0.198 & 0.162 & 8 & 4 & 0.054 & 4 & 1.000 & \\
\hline & & & -0.06 & -0.05 & -0.21 & & -0.27 & -0.02 & & & \\
\hline \multirow[t]{2}{*}{ ROA } & -0.139 & -0.103 & 3 & 1 & 5 & 0.337 & 5 & 6 & 0.019 & 0.025 & 1.000 \\
\hline & & & -0.02 & -0.04 & -0.10 & & & -0.03 & & & -0.14 \\
\hline LOSS & -0.025 & -0.032 & 5 & 5 & 0 & 0.075 & 0.166 & 5 & 0.098 & -0.081 & 2 \\
\hline
\end{tabular}


Table 4. Hypotheses Tests

\begin{tabular}{|c|c|c|}
\hline & Model 1 & Model 2 \\
\hline PBoard (H1) & $\begin{array}{l}0.093 \\
(1.99)^{* *}\end{array}$ & $\begin{array}{l}0.123 \\
(1.94)^{* *}\end{array}$ \\
\hline PBoard *SOE (H2) & & $\begin{array}{c}-0.141 \\
(1.84)^{*}\end{array}$ \\
\hline PCEO & $\begin{array}{l}-0.006 \\
(0.13)\end{array}$ & $\begin{array}{c}0.064 \\
(1.72)^{*}\end{array}$ \\
\hline SIZE & $\begin{array}{l}-0.009 \\
(0.31)\end{array}$ & $\begin{array}{l}0.018 \\
(1.16)\end{array}$ \\
\hline MTB & $\begin{array}{l}-0.006 \\
(0.85)\end{array}$ & $\begin{array}{l}0.001 \\
(0.21)\end{array}$ \\
\hline LEV & $\begin{array}{l}0.027 \\
(0.19)\end{array}$ & $\begin{array}{l}-0.161 \\
(1.54)\end{array}$ \\
\hline INV & $\begin{array}{l}0.234 \\
(1.39)\end{array}$ & $\begin{array}{l}0.457 \\
(3.53)^{* * *}\end{array}$ \\
\hline FIX & $\begin{array}{l}-0.049 \\
(0.31)\end{array}$ & $\begin{array}{c}0.331 \\
(3.12)^{* * *}\end{array}$ \\
\hline Tenure & $\begin{array}{l}-0.005 \\
(0.83)\end{array}$ & $\begin{array}{l}0.002 \\
(0.41)\end{array}$ \\
\hline ROA & $\begin{array}{c}-0.045 \\
(11.70)^{* * *}\end{array}$ & $\begin{array}{c}-0.040 \\
(12.63)^{* * *}\end{array}$ \\
\hline LOSS & $\begin{array}{c}-0.144 \\
(2.14)^{* *}\end{array}$ & $\begin{array}{l}-0.103 \\
(1.43)\end{array}$ \\
\hline SOE & & $\begin{array}{l}0.118 \\
(3.10)^{* * *}\end{array}$ \\
\hline Intercept & $\begin{array}{c}0.975 \\
(4.02)^{* * *}\end{array}$ & $\begin{array}{c}0.527 \\
(3.80)^{* * *}\end{array}$ \\
\hline Years & Included & Included \\
\hline Industries & Included & Included \\
\hline$R^{2}$ & 0.14 & 0.13 \\
\hline$N$ & 3,147 & 3,147 \\
\hline
\end{tabular}

${ }^{*} p<0.10 ; \quad * * p<0.05 ; * * * p<0.01$ 
Table 5. Robustness Tests

\begin{tabular}{|c|c|c|c|}
\hline & $\begin{array}{l}\text { Dependent } \\
\text { Variable: }\end{array}$ & \multicolumn{2}{|c|}{$\begin{array}{c}\text { Dependent Variable: } \\
\text { GAAP ETR }\end{array}$} \\
\hline & Tobit Model & Fixed Effects & Tobit Model \\
\hline PBoard (H1) & $\begin{array}{l}0.112 \\
(3.49)^{* * *}\end{array}$ & $\begin{array}{c}0.025 \\
(2.46)^{* *}\end{array}$ & $\begin{array}{l}0.025 \\
(2.58)^{* * *}\end{array}$ \\
\hline PBoard *SOE (H2) & $\begin{array}{l}-0.158 \\
(4.10)^{* * *}\end{array}$ & $\begin{array}{l}-0.035 \\
(2.78)^{* * *}\end{array}$ & $\begin{array}{l}-0.034 \\
(2.85)^{* * *}\end{array}$ \\
\hline PCEO & $\begin{array}{l}0.047 \\
(2.51)^{* *}\end{array}$ & $\begin{array}{l}-0.012 \\
(1.96)^{*}\end{array}$ & $\begin{array}{l}-0.013 \\
(2.24)^{* *}\end{array}$ \\
\hline SIZE & $\begin{array}{l}0.016 \\
(2.10)^{* *}\end{array}$ & $\begin{array}{l}0.002 \\
(0.85)\end{array}$ & $\begin{array}{l}0.002 \\
(0.85)\end{array}$ \\
\hline MTB & $\begin{array}{l}-0.002 \\
(0.66)\end{array}$ & $\begin{array}{l}-0.003 \\
(2.57)^{* *}\end{array}$ & $\begin{array}{l}-0.003 \\
(2.64)^{* * *}\end{array}$ \\
\hline LEV & $\begin{array}{l}-0.085 \\
(1.62)\end{array}$ & $\begin{array}{c}0.055 \\
(3.21)^{* * *}\end{array}$ & $\begin{array}{l}0.054 \\
(3.34)^{* * *}\end{array}$ \\
\hline INV & $\begin{array}{l}0.391 \\
(5.99)^{* * *}\end{array}$ & $\begin{array}{l}0.083 \\
(3.95)^{* * *}\end{array}$ & $\begin{array}{l}0.086 \\
(4.29)^{* * *}\end{array}$ \\
\hline FIX & $\begin{array}{l}0.076 \\
(1.42)\end{array}$ & $\begin{array}{l}0.002 \\
(0.14)\end{array}$ & $\begin{array}{l}-0.000 \\
(0.00)\end{array}$ \\
\hline Tenure & $\begin{array}{l}0.000 \\
(0.12)\end{array}$ & $\begin{array}{l}0.000 \\
(0.17)\end{array}$ & $\begin{array}{l}0.000 \\
(0.21)\end{array}$ \\
\hline $\mathrm{ROA}$ & $\begin{array}{l}-0.012 \\
(7.66)^{* * *}\end{array}$ & $\begin{array}{l}0.002 \\
(4.47)^{* * *}\end{array}$ & $\begin{array}{l}0.002 \\
(3.68)^{* * *}\end{array}$ \\
\hline LOSS & $\begin{array}{l}-0.097 \\
(2.57)^{* *}\end{array}$ & $\begin{array}{l}0.000 \\
(0.02)\end{array}$ & $\begin{array}{l}0.001 \\
(0.06)\end{array}$ \\
\hline SOE & $\begin{array}{c}0.078 \\
(4.10)^{* * *}\end{array}$ & $\begin{array}{l}0.001 \\
(0.20)\end{array}$ & $\begin{array}{l}0.002 \\
(0.40)\end{array}$ \\
\hline Intercept & $\begin{array}{c}0.354 \\
(62.97)^{* * *}\end{array}$ & $\begin{array}{l}0.150 \\
(6.62)^{* * *}\end{array}$ & $\begin{array}{c}0.113 \\
(76.66)^{* * *}\end{array}$ \\
\hline Years & Included & Included & Included \\
\hline Industries & Included & Included & Included \\
\hline$R^{2}$ & 0.31 & 0.03 & 0.01 \\
\hline$N$ & 3,147 & 3,147 & 3,147 \\
\hline
\end{tabular}

${ }^{*} p<0.10 ; \quad * * p<0.05 ; * * * p<0.01$ 